\title{
A Time-Series Analysis of Climate Variability in Urban and Agricultural Sites (Rome, Italy)
}

\author{
Luca Salvati ${ }^{1}$, Ilaria Zambon ${ }^{2,3}, * \mathbb{D}$, Giuseppe Pignatti ${ }^{1}$, Andrea Colantoni ${ }^{2}{ }^{\mathbb{D}}$, Sirio Cividino ${ }^{4}$, \\ Luigi Perini ${ }^{5}$, Giorgio Pontuale ${ }^{1}$ and Massimo Cecchini ${ }^{2}{ }^{\mathbb{C}}$ \\ 1 Council for Agricultural Research and Economics (CREA-FL), Via Valle della Quistione 27, I-00166 Rome, \\ Italy; luca.salvati@crea.gov.it (L.S.); giuseppe.pignatti@crea.gov.it (Giu.P.); \\ giorgio.pontuale@crea.gov.it (Gio.P.) \\ 2 Department of Agricultural and Forestry Sciences (DAFNE), Tuscia University, Via S. Camillo De Lellis snc, \\ I-01100 Viterbo, Italy; colantoni@unitus.it (A.C.); cecchini@unitus.it (M.C.) \\ 3 Department of Geography, University of Valencia, Av. de Blasco Ibáñez, 13, ES-46010 València, Spain \\ 4 Department of Agriculture, University of Udine, Via delle Scienze 206, I-33100 Udine, Italy; \\ agricolturasicura@gmail.com \\ 5 Council for Agricultural Research and Economics (CREA-AA), Via della Navicella 2-4, I-00184 Rome, Italy; \\ luigi.perini@crea.gov.it \\ * Correspondence: ilaria.zambon@unitus.it; Tel.: +39-0761-357356
}

Received: 27 March 2019; Accepted: 6 May 2019; Published: 8 May 2019

\begin{abstract}
Identifying early signals of climate change and latent patterns of meteorological variability requires tools analyzing time series data and multidimensional measures. By focusing on air temperature and precipitation, the present study compares local-scale climate regimes at two sites in Central Italy (urban Rome and a peri-urban cropland $10 \mathrm{~km}$ west of Rome), using descriptive and inferential statistics on both variables and a drought index (the Standardized Precipitation Index, hereafter SPI) recorded over the last 60 years (1958-2017). The present work assumes the importance of urban-rural gradients shaping local-scale climate regimes and spatial variability, with differential impacts on individual variables depending on territorial background and intrinsic biophysical characteristics. Considering together precipitations and minimum/maximum air temperature at month and year scale, the analysis developed here illustrates two coexisting climatic trends at distinctive spatial scales: A general trend toward warming-specifically influencing temperature regimes-and a more specific pattern evidencing changes in local-scale climate regime along the urban gradient, with a more subtle impact on both precipitations and temperatures. Empirical results indicate that climate variability increased over the study period, outlining the low predictability of dry spells typical of Mediterranean climate especially in the drier season (spring/summer). On average, absolute annual differences between the two sites amounted to $70 \mathrm{~mm}$ (more rainfall in the peri-urban site) and $0.9^{\circ} \mathrm{C}$ (higher temperature in the urban site). A similar trend toward warming was observed for air temperature in both sites. No significant trends were observed for annual and seasonal rainfalls. SPI long-term trends indicate high variability in dry spells, with more frequent (and severe) drought episodes in urban Rome. Considering together trends in temperature and precipitation, the 'urban heat' effect was more evident, indicating a clearer trend toward climate aridity in urban Rome. These findings support the adoption of integrated strategies for climate change adaptation and mitigation in both agricultural systems and relict natural ecosystems surrounding urban areas.
\end{abstract}

Keywords: climate variations; precipitation; air temperature; Central Italy; Mediterranean region 


\section{Introduction}

Climate regimes showed sequential 'cold' and 'hot' waves in last centuries impacting significantly ecosystems and societies [1]. The average surface temperature grew by more than $0.7^{\circ} \mathrm{C}$ in the last century and the time period between 1995 and 2007 was recognized as the warmest since 1850 [2-4]. Incorporating time series data available up to now, future climate projections indicate a different scenario from the current averages, foreshadowing a global warming [5] associated with a moderate decrease in rainfalls and locally-severe changes in wind direction and intensity, air pressure and soil humidity [6]. A higher variability of pertinent weather variables was also observed, exacerbating land sensitivity to both droughts and floods [7-11]. Being situated in a transitional region between two climatic systems (tropical and polar), the Mediterranean basin is one of the most sensitive areas to climate change worldwide. Geographical position and territorial factors (e.g., elevation and distance from the sea coast), play a crucial role in shaping climate regimes in the area, determining a particularly high rainfall and temperature variability along the elevation gradient [12]. Climate variability was associated with (i) an increase in average air temperature and (ii) a rise in vegetation stress caused by a mix of progressively higher summer temperatures, lower air humidity, lower rainfall rates and improved extreme events $[6,13,14]$.

Together with climate aridity [15], land-use change and increased human pressure, environmental processes emerged with global warming [16-22]. For instance, Land Degradation (LD) was increasingly associated with climate change and its effects negatively impact soil quality determining a decrease in land productivity, biodiversity and ecosystem services [23-27]. Therefore, climate variations are related with life-threatening ecological conditions $[6,28-30]$ and require appropriate mitigation and adaptation policies [31]. Considering urbanization as a powerful factor of landscape transformations in Mediterranean Europe, a comparison of changes over time in local-scale climate regimes (e.g., between urban and peri-urban areas) is particularly stimulating in the light of global vs local climate change, drought and land degradation [32]. While climate change is a recognized phenomenon worldwide, an additional factor related to local changes in climate regimes is urban expansion, which generate a well-known effect known as the Urban Heat Island, hereafter UHI [33]. The UHI usually leads to local climate change, with rising temperatures and extreme rainfall events [33-36]. The UHI consequences involve planning challenges that should increasingly consider the negative environmental impact of climate change and urbanization together [37], mitigating less effectively the rapid increase in temperatures within urban areas in respect with the surrounding areas $[38,39]$. Earlier studies have focused on inner cities, since UHI stress resulted more pervasive in those places than in peri-urban sites [40,41]. However, a specific investigation of long-term trends in rainfall and temperature comparing urban and neighboring peri-urban sites is still lacking in Mediterranean large cities experiencing rapid urban expansion.

In such contexts, strategies of mitigation and adaptation incorporated in town planning are specifically requested to consider the expected increase in urban heat stress [38,42,43]. However, identifying signals of climate change and increased variability in rainfall and temperature regimes needs improved tools investigating large data sets, possibly based on multidimensional procedures [44]. Defining a homogeneous temporal unit is a prerequisite in the analysis of linear and non-linear long-term trends in temperatures and rainfall, time series break-points and latent relations among meteorological variables. This knowledge forms the necessary base to policy implementation in the field of mitigation and adaptation of climate change in large urban regions.

Based on these premises, our study investigates variability in precipitation and air temperature over a sufficiently long time period (1958-2017) in Rome (Central Italy), comparing trends at an urban site (Collegio Romano, downtown Rome) and at a peri-urban site (Casalotti, a suburb west of Rome). Using descriptive and inferential statistics on both original variables and a drought index (the Standardized Precipitation Index, hereafter SPI), the quantitative analysis developed in this work is aimed at identifying two coexisting trends in regional-scale climate regimes: (i) A general trend toward warming and (ii) a more specific pattern evidencing changes in local-scale climate regime 
along the urban gradient, and likely involving both temperature and precipitations. Similarly, to other Mediterranean sites $[5,13,45]$, the study area experienced increased climate variations in the last decades. Climate regimes in central Italy, and especially in Rome's metropolitan region, modified relatively rapidly over time and space due to a different influence of environmental conditions and socioeconomic forces at local and regional scales [46]. Results of the present study are particularly relevant also for the intrinsic impact of local-scale climate change on specific economic activities. For instance, agriculture is a traditional activity in peri-urban Rome, recognized and practiced since millennia. Impact of global and local warming on peri-urban agriculture should be better investigated in Mediterranean Europe with the final objective to inform local policies increasing resilience of fringe cropping systems to climate change [47]. In the light of global warming and reinforced urban heat effects, results of this study may contribute to identify sustainable management options for these contexts, improving adaptation to climate change.

\section{Methodology}

Two sites were considered in this study: Collegio Romano (downtown Rome, $16 \mathrm{~m}$ at the sea level) and Casalotti (western Rome, $80 \mathrm{~m}$ at the sea level) (Figure 1). These contexts were taken as representative of a strictly urban area and a peri-urban area, respectively. Meteorological data were acquired from professional, international standard weather stations operating continuously and producing high-quality data (with no missing values) over the entire study period. The two databases are homogeneous, without missing data, and this has made gap filling procedures unnecessary. Collegio Romano station was one of the historical weather stations in Italy, measuring meteorological variables since the end of the 18th century. Data from both gauging stations were extensively used in official statistics and national/regional reporting of climate conditions prepared by public authorities in charge of public works, environmental management, agriculture and forestry. Casalotti station is placed in a peri-urban context rich in green spaces, with sparse forest patches embedded in the 'Agro Romano' landscape, forming a typical mosaic of farmland, pastures, woods and wetlands. This landscape was increasingly exposed to urban expansion, soil degradation, wildfires and indirect human pressure [48-51]. The municipal territory of Rome extends $1285 \mathrm{~km}^{2}$, being the inner more urbanized part, encircled by a ring-shaped motorway called Grande Raccordo Anulare, with a total length of $345 \mathrm{~km}^{2}$.

The urban system extended from about 7\% of the municipal area in 1960 to nearly $27 \%$ in 2015 [52]. During the first 20 years of the study period, urban expansion was mainly restricted to the inner part of the municipality, followed by peripheral, less compact urbanization. Changes in land-use between 1980 and 2001 show, beside the increment of urban areas, a decrease of extensive agricultural land-use (not irrigated arable land, complex cultivation patterns, sparsely vegetated areas), and the increase of intensive agriculture and forest systems (permanently irrigated arable land, reforestations), as well as semi-natural mixed systems (forests and woodland shrubs) [53]. At the end of the 1990s, about $50 \%$ of the municipal area remained cultivated, mainly in peri-urban areas. Figure 1 illustrates aerial photographs of the two sites derived from Google Earth imagery (Figure 1a,b) and is enriched with specific maps of early 1950s (Figure 1c,d), other more recent urbanization derived from Corine Land Cover maps (Figure 1e,f) and a comprehensive land imperviousness assessment carried out by European Environment Agency in the framework of Land Copernicus initiative (Figure 1g,h). Average month data of air temperatures and precipitations between 1958 and 2017 were considered in this study. Using averages and other statistical indexes, data were aggregated at both annual and seasonal scale grouping years by 6 decades, 3 consecutive periods of 20 years $(1958-1967, \ldots, 2008-2017)$ and 2 consecutive periods of 30 years. 

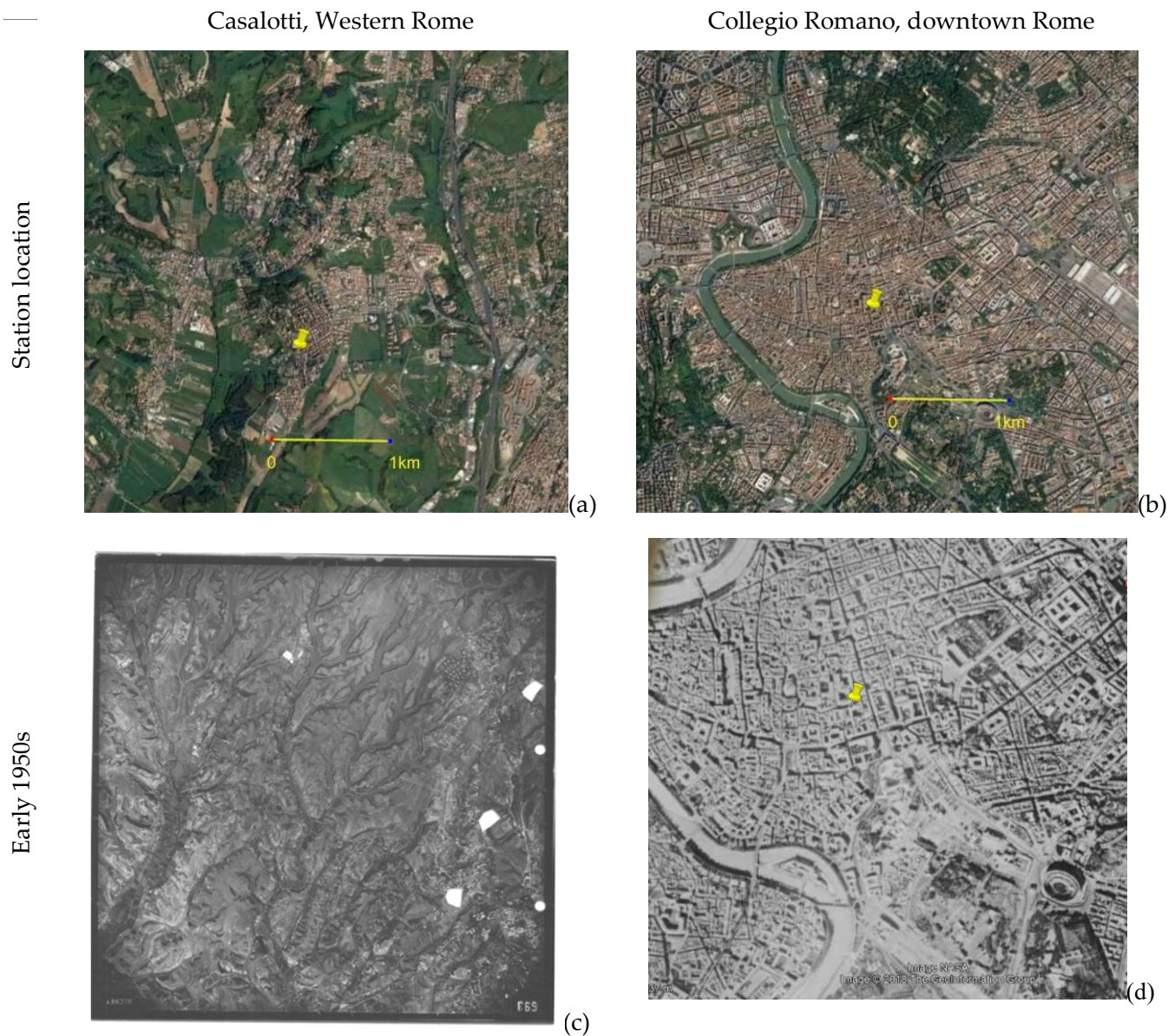

(c)
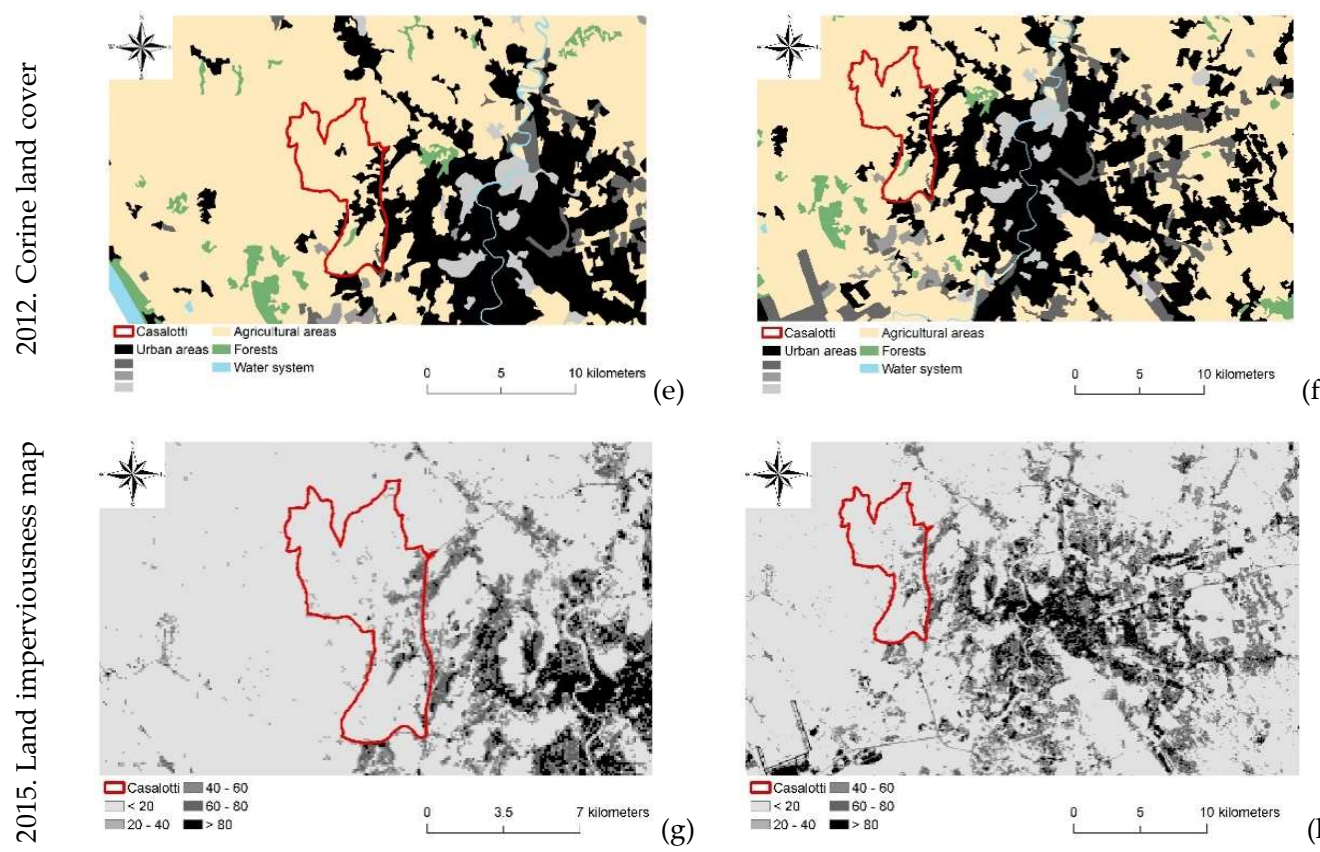

(h)

Figure 1. Maps illustrating location and basic characteristics of the two sites: Casalotti (peri-urban) and Collegio Romano (strictly urban): aerial photographs derived from Google Earth imagery of Casalotti (a) and Collegio Romano (b); maps of early 1950s of Casalotti (c) and Collegio Romano (d); maps of recent urbanization derived from Corine Land Cover maps of Casalotti (e) and Collegio Romano (f); and land imperviousness maps of Casalotti (g) and Collegio Romano (h) carried out by European Environment Agency in the framework of Land Copernicus initiative. 
Descriptive statistics were used to evaluate variability over time in air temperatures and precipitations at a year scale. The Standardized Precipitation Index (SPI) is defined as and can be interpreted as the number of standard deviations by which the observed $x$ (in this case the precipitation value) anomaly deviates from the long-term mean. Being used at three different time scales (1 month, 3-months, 6-months), the SPI was further calculated to provide a general overview of drought regimes, comparing the two locations. By computation on cumulated rainfalls over a given time horizon, the SPI is a convenient tool for monitoring meteorological drought, whose assessment is traditionally based on precipitation data. It gives a flexible method to assess drought at a different scale [52,53] extending from near normal $(-0.99)$ to extreme drought conditions $(\leq-2.0)$ [54-60]. SPI values greater than 2 indicate extremely wet conditions, while those less than -2 indicate extreme drought conditions. Using different time windows with the aim to investigate seasonal regimes, total precipitations were recorded. Finally, a composite index proposed by Perini et al. [61] was run to evaluate together precipitation and temperature trends over time. By cumulating the local effect of both variables, this index ranges from 1 (indicating a wet climate regime, with lower temperatures and higher precipitations) to 0 (indicating a drier climate regime, with higher temperatures and lower precipitations). A progressive decrease of the index indicates a trend over time toward climate aridity.

$$
\operatorname{SPI}(x)=\frac{x-\langle x\rangle}{\sigma(x)}
$$

\section{Results}

Time series data comparing climate trends in Rome and Casalotti between 1958 and 2017 were analyzed considering together average air temperatures and precipitations at both month and year time scale.

\subsection{Rainfall}

At both sites, precipitation was particularly heterogeneous over time as expected in a Mediterranean dry zone. Precipitations in Casalotti showed high variability over time with a minimum of $443 \mathrm{~mm}$ in 2007 and a maximum of $1294 \mathrm{~mm}$ in 1976 (Table 1 and Figure 2a). The annual average precipitation was $802 \mathrm{~mm}$ with a standard deviation of $188 \mathrm{~mm}$ and a coefficient of variation amounting to $23.4 \%$ (Table 1). In Collegio Romano, precipitations showed a relatively heterogeneous trend over time, with a minimum of $426 \mathrm{~mm}$ in 2017 and a maximum of $1045 \mathrm{~mm}$ in 1976 (Figure 2b) and overall average value of $711 \mathrm{~mm}$, standard deviation of $156.5 \mathrm{~mm}$ and coefficient of variation amounting to $22.0 \%$. Absolute differences in total precipitations between Casalotti and Collegio Romano (Figure 2c) were particularly intense in 1975 (327 mm), assuming the opposite pattern in $2008(-322 \mathrm{~mm})$. The absolute difference between precipitation averages at the two sites was $91 \mathrm{~mm}$.

A one-way ANOVA test on the two annual rainfall time series allows to reject the null hypothesis that the means of the two sites are equal $(\mathrm{F}=8.25, p=0.0048)$ and the observed differences are due to statistical fluctuations. Moreover, the necessary condition for ANOVA test that the two variances are similar is guaranteed (Levene' test, $\mathrm{F}=2.62, p=0.108$ ); this endorses that the observed greater average precipitation in Casalotti is attributable to random fluctuations. A normality test (Kolmogorov-Smirnov) on the two-time series finally allows to accept $(p>0.8$ for both sites) the assumption of Gaussian distribution of time series data.

Figure 3 exposes the time series of the annual SPI (broken lines) and 5-order polynomial fitting curves (red curves) in Casalotti and Collegio Romano annually (from 1958 to 2017). From the same time period, Figure 4 reports the temporal trend concerning air temperature in Casalotti (a) and Collegio Romano (b). Furthermore, absolute difference between Casalotti and Collegio Romano by year was portrayed (Figure 4c). The blue line outlines the observed values, defining the trends of air temperature; while, the red line permits to draw the trend line in time, offering the corresponding equation. 
Table 1. Summary statistics of different temporal rainfalls at Casalotti and Collegio Romano sites, 1958-2017; (AUT = autumn, INV = winter, PRI = spring, EST = summer).

\begin{tabular}{cccc}
\hline & & Casalotti & Collegio Romano \\
\hline \multirow{5}{*}{ Annual } & Min (mm) & $443(2007)$ & $426(2017)$ \\
& Max (mm) & $1294(1976)$ & $1045(1976)$ \\
& Average (mm) & 802 & 711 \\
& $\sigma(\mathrm{mm})$ & 188.0 & 156.5 \\
\multirow{2}{*}{6 Months } & CoV (\%) & 23.4 & 22.0 \\
& Average (AUT+INV) & 546.0 & 476.0 \\
& Average (PRI+EST) & 255.0 & 235.0 \\
\hline \multirow{5}{*}{3 Months } & Average AUT & 303 & 271 \\
& Average INV & 244 & 206 \\
& Average PRI & 178 & 78 \\
& Average EST & 77 & 533 (AUT 1991) \\
& Max (mm) & 672 (AUT 1962) & 1.4 (EST 1993) \\
\hline
\end{tabular}
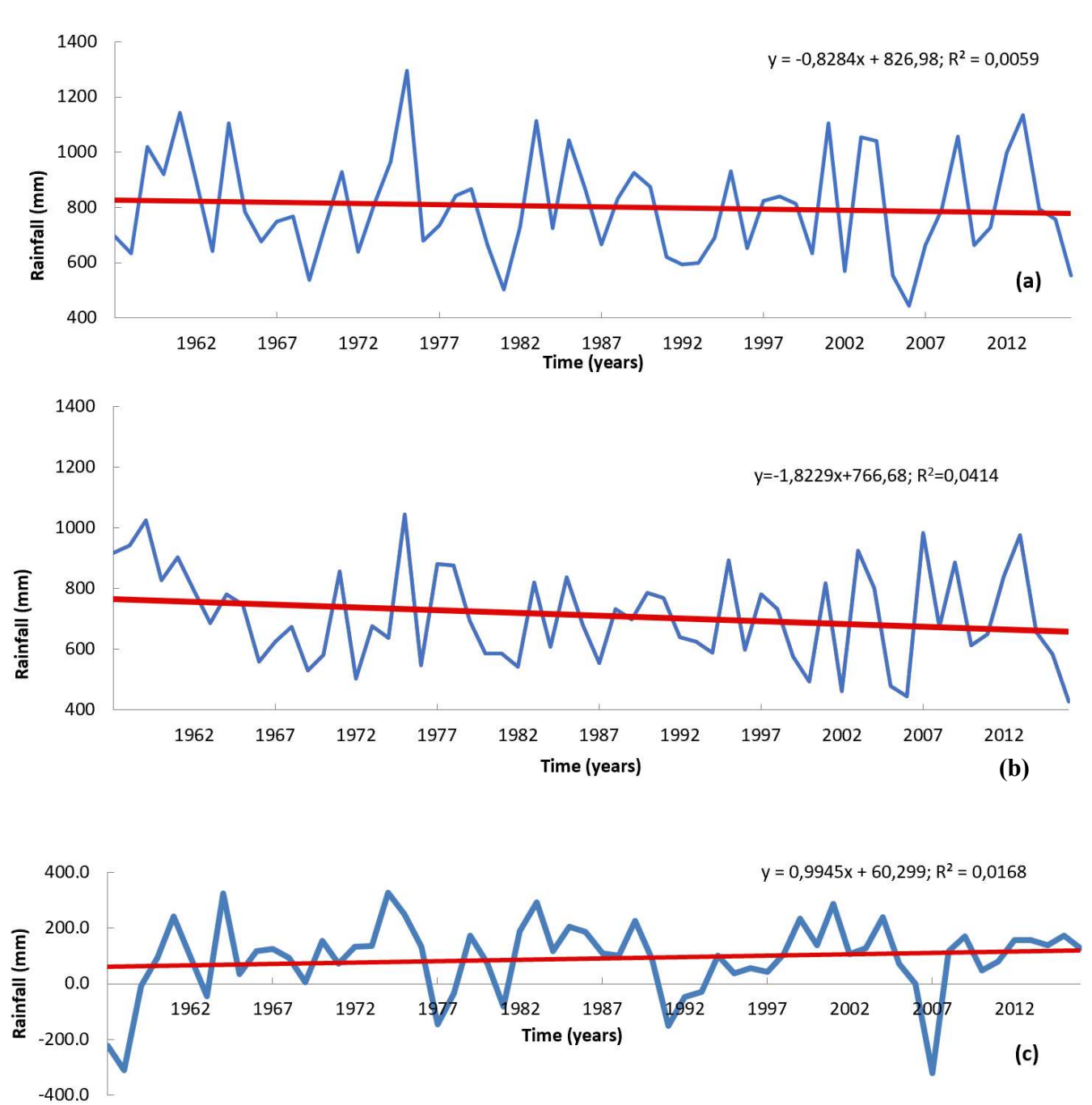

Figure 2. Annual rainfall in Casalotti (a) and Collegio Romano (b) and absolute difference (mm) between Casalotti and Collegio Romano (c) by year, 1958-2017. 

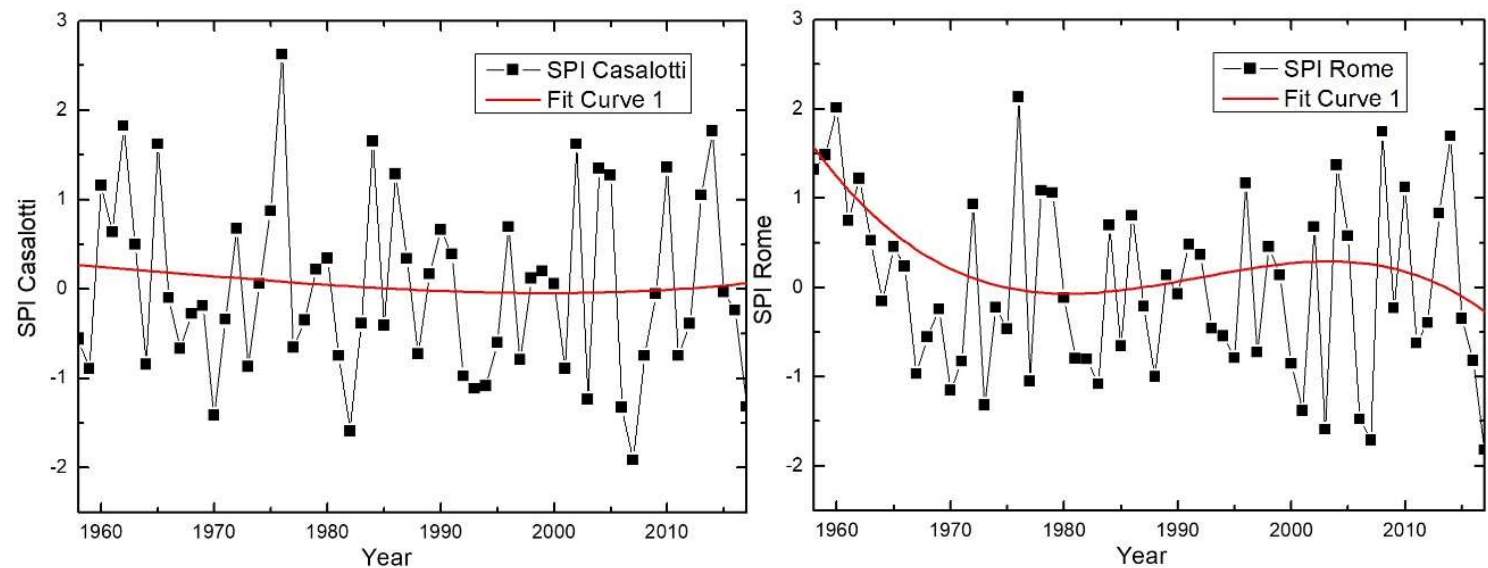

(a)

Figure 3. Time series of the annual SPI (broken lines) and 5-order polynomial fitting curves (red curves) in Casalotti (a) and Collegio Romano (b), by year, 1958-2017.

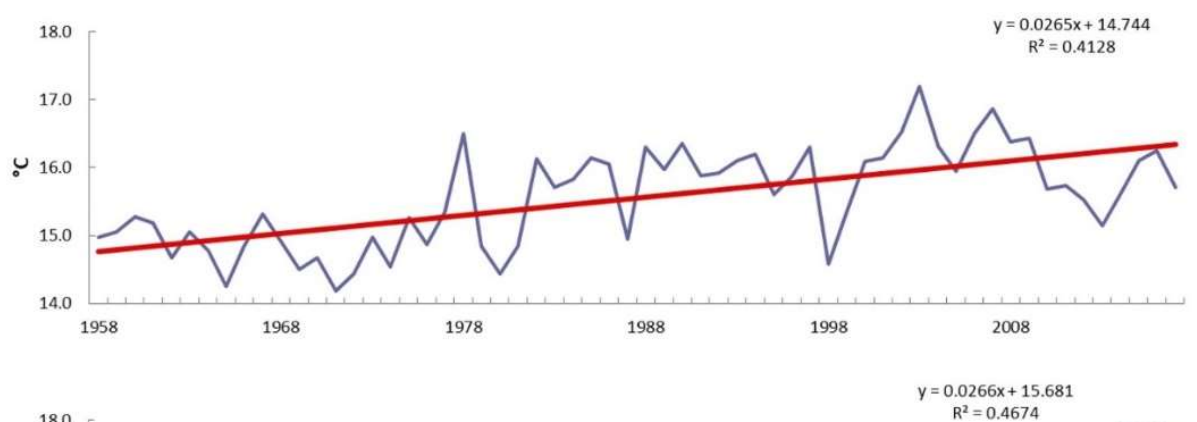

(a)

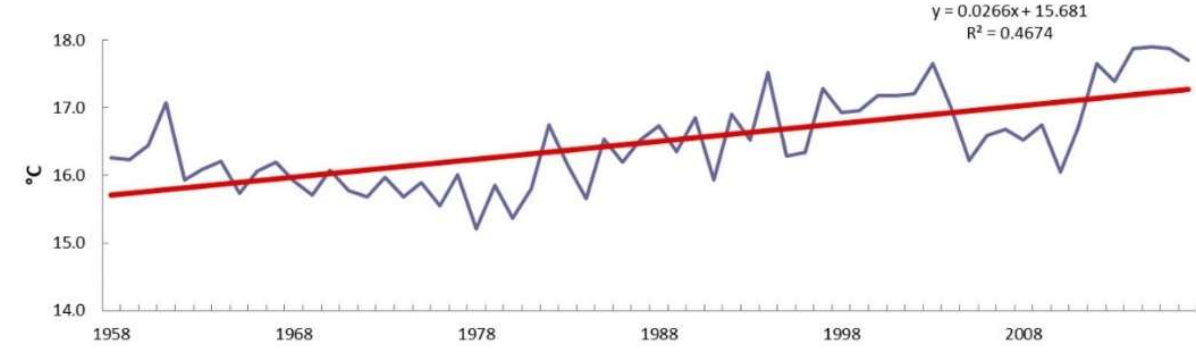

(b)

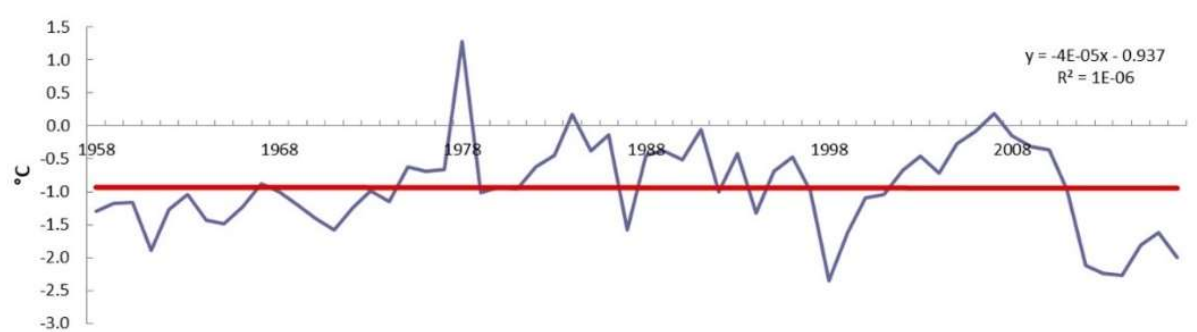

(c)

Figure 4. Trend over time in air temperature, Casalotti (a) and Collegio Romano (b), and absolute difference between Casalotti and Collegio Romano by year (c), 1958-2017.

By computation on total precipitation over a given time horizon, a Standardized Precipitation Index (SPI) provided a general overview of drought regimes in the area (Figure 5). Considering a 3-months' time window with the aim to investigate seasonal drought regimes, a total precipitation of $244 \mathrm{~mm}$ in winter (INV), $178 \mathrm{~mm}$ in spring (PRI), $77 \mathrm{~mm}$ in summer (EST) and $303 \mathrm{~mm}$ in autumn (AUT) was recorded, on average, in Casalotti. In Collegio Romano, a total precipitation of $206 \mathrm{~mm}$ in winter, $157 \mathrm{~mm}$ in spring, $78 \mathrm{~mm}$ in summer and $271 \mathrm{~mm}$ in autumn was observed. The maximum 
precipitation observed in Casalotti was $672 \mathrm{~mm}$ in 1962 autumn; the minimum precipitation was observed in summer 2000 ( $0 \mathrm{~mm}$ ); in Collegio Romano, the maximum cumulated rainfall was observed in autumn 1991 (533 $\mathrm{mm}$ ) and the minimum in summer $1993(1.4 \mathrm{~mm})$. Although few severe drought spells were observed in the study period, lower SPI scores were observed in such episodes in Collegio Romano than in Casalotti, especially in winter and autumn, corresponding to climatically wet periods in a typical Mediterranean climate, when the largest amount of rainfall is expected. Two severe drought episodes were observed in autumn (SPI $<-2)$ for Collegio Romano.

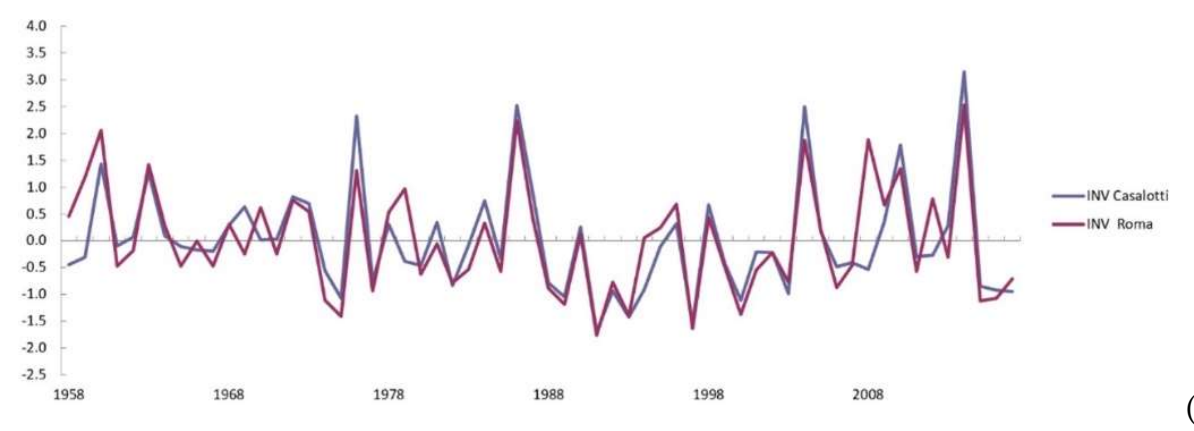

(a)

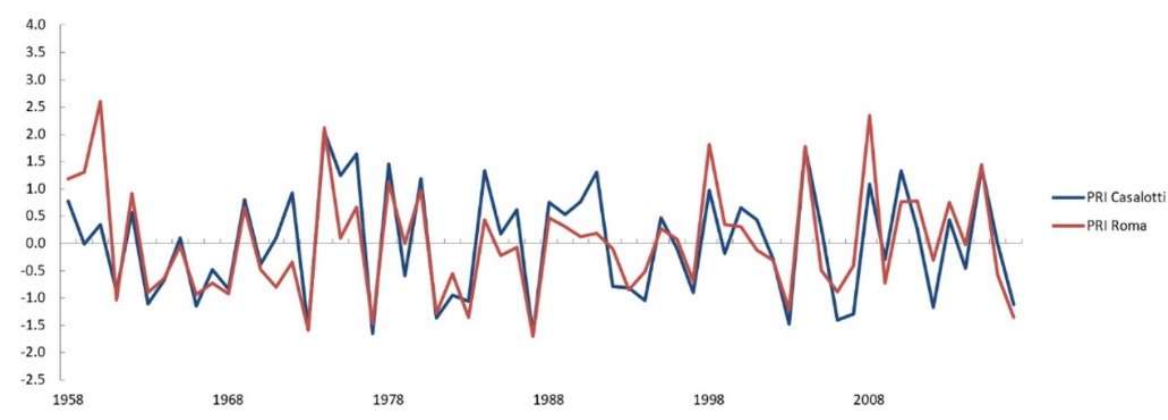

(b)
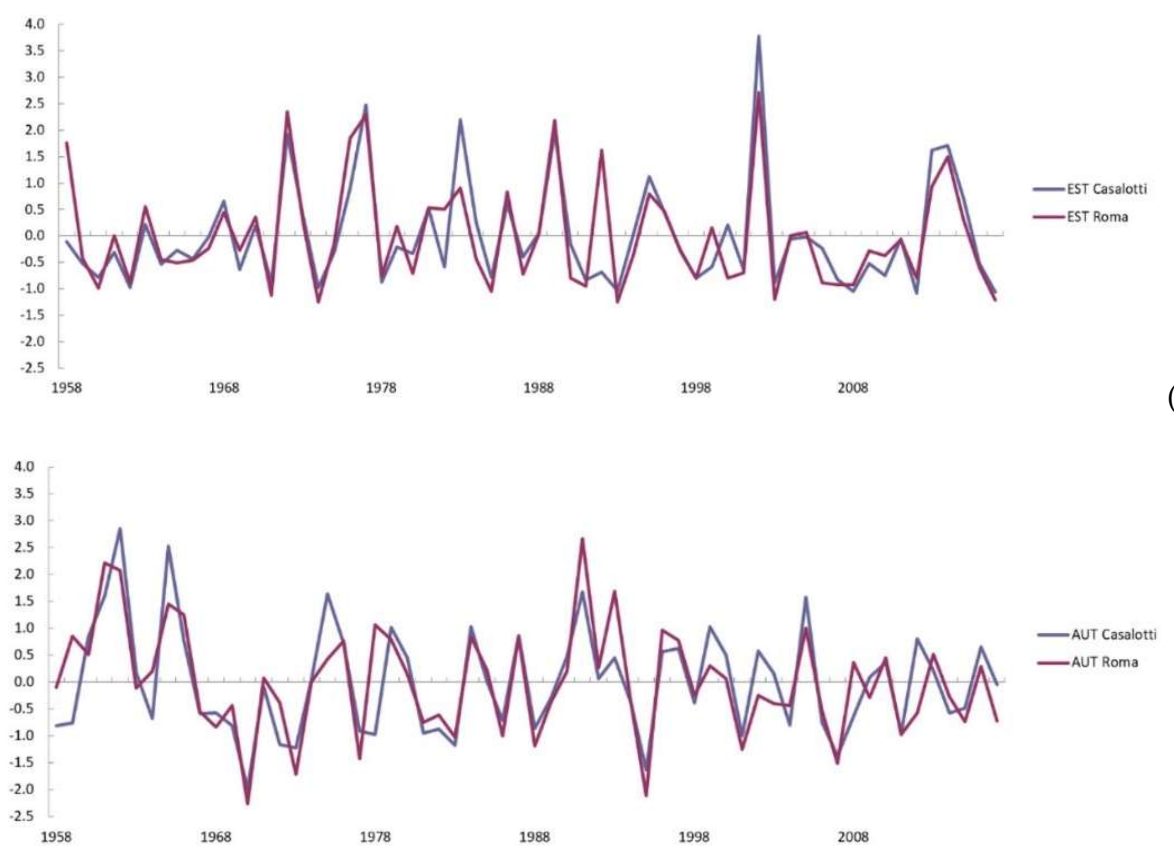

Figure 5. Standardized Precipitation Index (3 months' time window) in Casalotti (blue) and Collegio Romano (red) by year, 1958-2017, from top to low panels: winter (a), spring (b), summer (c) and autumn (d). 
Considering a time period of 6 months, a marked gap in cumulated rainfalls was observed between Collegio Romano and Casalotti. Average cumulated precipitations during wet (autumn and winter) and dry seasons (spring and summer) were respectively $546 \mathrm{~mm}$ and $255 \mathrm{~mm}$ in Casalotti; in Collegio Romano, average cumulated rainfall in autumn and winter was $476 \mathrm{~mm}$ and only $235 \mathrm{~mm}$ in spring and summer (Figures 6 and 7). Although particularly severe droughts were not observed at this time window, at least 5 and 7 episodes of moderately-severe droughts were observed in the area (SPI $<-1.5$ ) respectively during dry and wet seasons (Figure 6a,b). Under time periods with negative SPI, more negative values were systematically observed in Collegio Romano than in Casalotti.

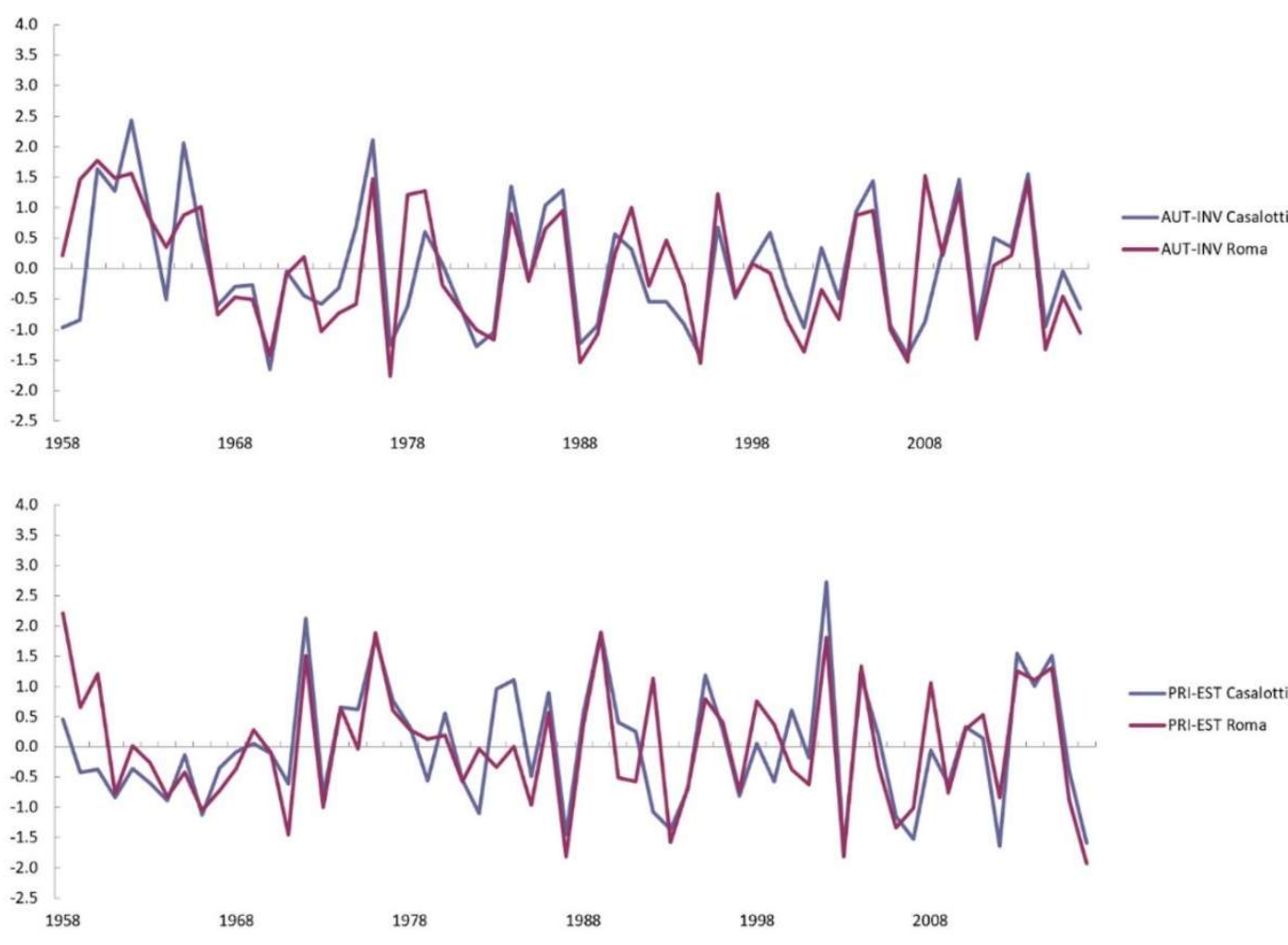

(a)

Figure 6. Standardized Precipitation Index (6 months' time window) in Casalotti (blue) and Collegio Romano (red) by year, 1958-2017 from top to low panels: autumn-winter (a) and spring-summer (b).

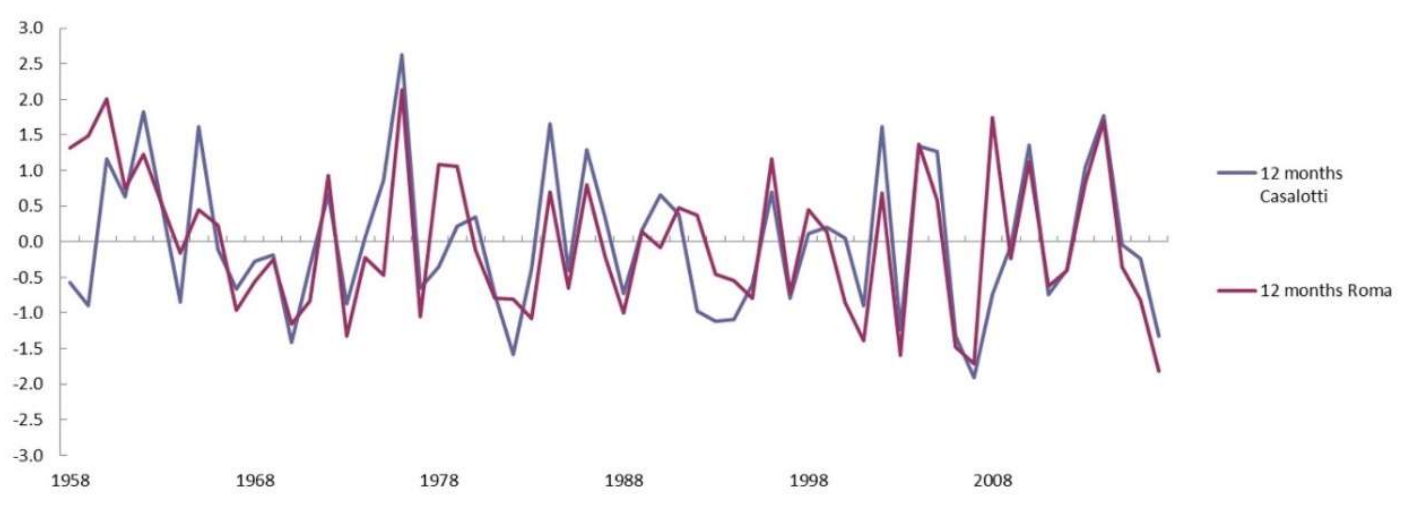

Figure 7. Standardized Precipitation Index (12 months' time window) in Casalotti (blue) and Collegio Romano (red) by year, 1958-2017.

Assuming a time window of 12 months, average cumulated rainfall was higher in Casalotti $(802 \mathrm{~mm})$ than in Rome $(711 \mathrm{~mm})$ (Figure 7). Moderately severe episodes of drought were concentrated in the last two decades and show a relatively similar intensity in both Casalotti and Collegio Romano. 
Analysis of climate variability based on ordinary least square regressions (Figure 2a,b), has been supplemented with a Mann-Kendall test-a non-parametric inference mainly used with non-gaussian data distributions-assessing the statistical relevance of monotonic upward or downward trends over time. Results of this test (Table 2) indicate the absence of any significant trend for both annual and seasonal precipitations along the analyzed time-series.

Table 2. Mann-Kendall statistics: $z$-values and $p$-values related to the annual and seasonal precipitation time series for urban (Collegio Romano) and rural (Casalotti) sites.

\begin{tabular}{ccccc}
\hline & \multicolumn{2}{c}{ Casalotti } & \multicolumn{2}{c}{ Collegio Romano } \\
\cline { 2 - 5 } & z Stat & $p$-Value & z Stat & $p$-Value \\
\hline Annual Rainfall & 0.702 & 0,483 & 1.543 & 0.123 \\
III-V months & 0.019 & 0.985 & 0.306 & 0.759 \\
VI-VIII months & 0.351 & 0.731 & 0.791 & 0.429 \\
IX-XI months & 0.019 & 0.985 & 1.454 & 0.146 \\
XII-II months & 1.499 & 0.136 & 1.180 & 0.241 \\
\hline
\end{tabular}

These last results do not exclude a-priori changes in specific climatic variables, especially for extreme events that represent the most attractive topic under the climate change literature $[62,63]$. Extreme drought and precipitation can cause considerable damage to agriculture, human economies, people's livelihood and property, and even influence the social stability of entire regions [63-65]. Earlier studies suggest that the mean of a distribution has very little relationship to extremes and it has been shown that extremes may change to a greater extent than changes in mean [66-68]. A 5-order polynomial fitting method applied to the average annual FED (Frequency of Extreme Drought) has been used in order to study differences as well as commonality among different subareas from 1961 to 2015 in a Chinese site [69]. A similar approach is applied here to analyze possible variations in time for the SPI annual values of the two sites. To some extent, the SPI is a sensitive variable reflecting meteorological droughts, soil moisture variations and extreme precipitation events [70,71]. In Figure 3a time series of the annual SPI (broken lines) and 5-order polynomial fitting curves (red lines) are shown for Casalotti (a) and Collegio Romano (b) by year, 1958-2017. A F-test is performed to verify the $\mathrm{H}_{0}$ hypothesis that the fitting model significantly differs from a constant model. While the fitting model for Casalotti does not describe any trend different from a trivial constant behavior $(\mathrm{F}=0.163, p=0.96)$, for Collegio Romano a weak, significant trend ( $\mathrm{F}=3.40, p=0.015)$, was observed. More specifically, it is possible to observe a marked SPI decrease until the 1980s, a slight upturn until 2005 and then definitely a downturn again until today, showing a trend towards longer droughts.

\subsection{Temperature}

The average annual temperature showed relevant variations over time in Casalotti, with a minimum of $14.2{ }^{\circ} \mathrm{C}$ in 1971 and a maximum of $17.2^{\circ} \mathrm{C}$ in 2003 (Figure 3a). The overall average temperature was $15.6^{\circ} \mathrm{C}$ with a standard deviation of $0.7^{\circ} \mathrm{C}$. In Collegio Romano, rainfall data indicated a minimum of $15.2^{\circ} \mathrm{C}$ in 1978 and a maximum of $17.9^{\circ} \mathrm{C}$ in 2015 (Figure 3b). The overall average temperature was $16.5^{\circ} \mathrm{C}$ with a standard deviation of $0.4{ }^{\circ} \mathrm{C}$. These results, summarized in Table 3, indicate that, on average, temperature regime in Rome was $0.9^{\circ} \mathrm{C}-1.0^{\circ} \mathrm{C}$ higher than in Casalotti, while temperature increases over time were substantially similar in both sites.

Table 3. Summary statistics of annual average temperature at Casalotti and Collegio Romano sites, 1958-2017.

\begin{tabular}{cccccc}
\hline Site & $\operatorname{Min}\left({ }^{\circ} \mathbf{C}\right)$ & $\operatorname{Max}\left({ }^{\circ} \mathbf{C}\right)$ & Average $\left({ }^{\circ} \mathbf{C}\right)$ & $\sigma\left({ }^{\circ} \mathbf{C}\right)$ & $\mathbf{C o V}(\%)$ \\
\hline Casalotti & $14.2(1971)$ & $17.2(2003)$ & 15.6 & 0.72 & 4.6 \\
Collegio Romano & $15.2(1978)$ & $17.9(2015)$ & 16.5 & 0.40 & 2.4 \\
\hline
\end{tabular}


A One-way ANOVA test on the two average temperature time series allows to reject the null hypothesis, with a 0.05 level of significance, that the means of the two sites are equal, and that the observed differences are due to statistical fluctuations $(\mathrm{F}=53.0, p<0.001)$. Moreover, the necessary condition for ANOVA test that the two variances are similar has been confirmed (Levene test, $\mathrm{F}=0.36$, $p=0.55)$. A normality test (Kolmogorov-Smirnov) on the two-time series allows to accept $(p>0.57$ for both sites) the assumption of Gaussian distribution of data for both locations.

For both sites, average temperature time series exhibited a slight upward trend, as revealed by a significant regression trend $\left(\mathrm{R}^{2}>0.4\right)$ with a similar positive slope $(\cong 0.026)$ and intercept $\left(\cong 15^{\circ} \mathrm{C}\right)$. An overall F-test allows to accept the hypothesis of a statistically significant (at a 0.05 level of significance) positive liner trend for both sites $(\mathrm{F}>40, p<0.001)$. A composite index, proposed by Perini et al. [72] and evaluating together standardized precipitations and temperatures (1: wet climatic regime; 0 : dry climate regime), indicates a trend toward climate aridity over the study period. This trend was significant and particularly intense in Rome $\left(R^{2}=0.34\right)$ and less evident in Casalotti $\left(R^{2}=0.16\right)$, as clarified with the use of regression coefficients (Figure 8). For both sites, F-test of overall significance provides sufficient evidence $(p<0.001)$ that the regression model fits the data better than the model with no independent variables. A steep regression slope in Collegio Romano indicates increasing aridity and a milder increase was observed in Casalotti. Taken together, these results indicate a clear trend toward local warming in both sites, with climate aridity being more evident in the urban site in the last decade.

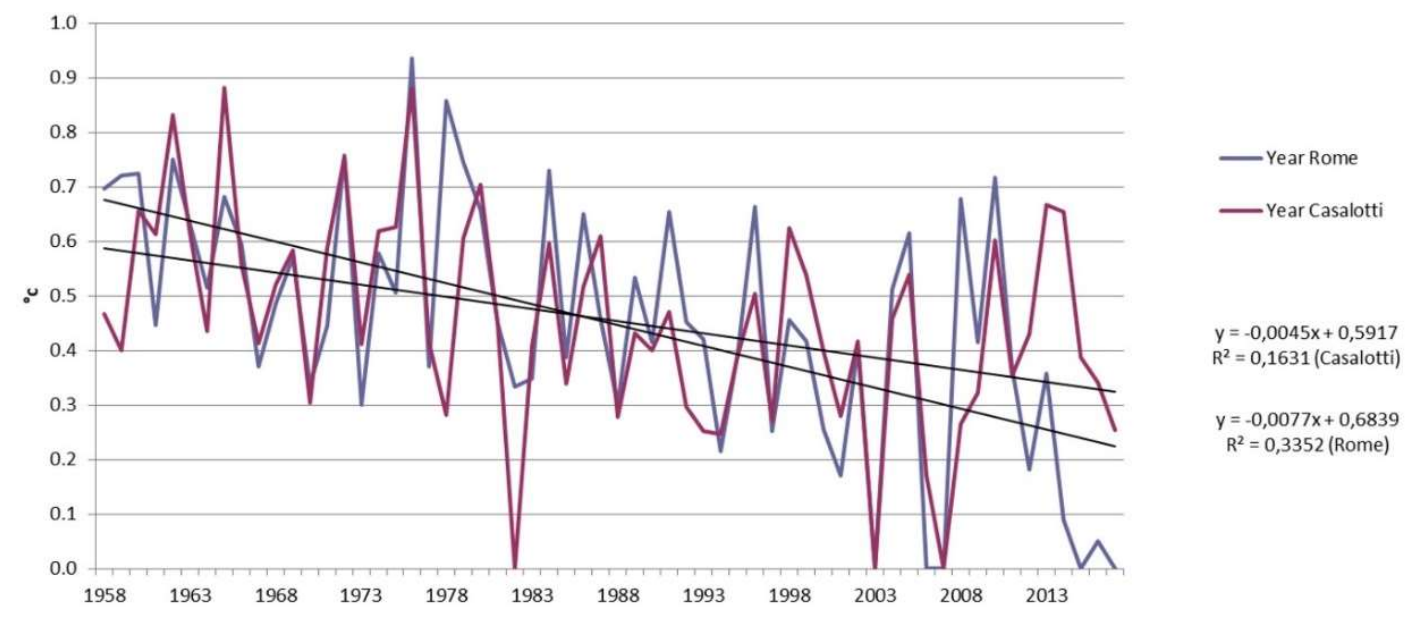

Figure 8. Trends over time in a composite index of climate aridity incorporating standardized precipitations and temperatures.

\section{Discussion}

Earlier studies focused on climate change and local-scale variability in last decades, examining mostly thermometric records [61,73-80], under the assumption that surface air temperature raised by $0.5-0.7^{\circ} \mathrm{C}$ since the beginning of the 20th century. Climate analysis over a relatively long-time interval provides a relevant knowledge base to infer the impact of meteorological variables on soil moisture, vegetation growth, crop productivity and ecosystem stability [81], particularly in areas under widespread human pressure [82]. Comparison of local-scale climate regimes between neighboring sites with different land-use and landscape configurations (e.g., along the urban-rural gradient in large metropolitan regions) may provide useful indications to a better understanding of climate variability patterns, distinguishing regional patterns of change (e.g., global warming trends) from modifications in local climate mostly due to rapid urban expansion. The latter process contributed to determine 'urban heat' effects on both temperature and precipitation regimes.

Climate variability resulted to increase over the study period, delineating the low predictability of dry spells typical of Mediterranean climate particularly in the drier season (both spring and summer). 
The empirical results of this study evidenced (i) local warming $\left(0.7^{\circ} \mathrm{C}\right.$ over 60 years) with a comparable trend between sites; (ii) site-specific differences in the aridity regime (considering together the joint effect of temperature and precipitations), with drier conditions in downtown Rome than in suburban Rome; (iii) this last statement is supported by a non-trivial, stable trend of the 12-months SPI in downtown Rome, turning toward a drier regime in the last few years. On average, absolute annual differences among the two sites amounted to $70 \mathrm{~mm}$ (more rainfall in the peri-urban site) and $0.9^{\circ} \mathrm{C}$ (higher temperature in the urban site). A comparable trend toward warming was detected for air temperature in both sites. The persistent gap in average temperatures between sites $\left(0.9^{\circ} \mathrm{C}\right.$ higher in Rome than in Casalotti, on average) can be attributable to specific site characteristics, including massive urbanization of inner Rome before the late 1950s, corresponding with the beginning of the observation period. With urban settlements expanding rapidly in Rome between 1960 and 2015 [52], the assumption of a direct influence of urban growth on local warming seems reasonable.

Results also exposed that no significant trends were observed for annual and seasonal rainfalls. SPI long-term trends designate high variability in drought spells, with more frequent (and severe) episodes in the urban city of Rome than the countryside's area. Bearing in mind together trends in temperature and precipitation, the 'urban heat' effect was more apparent in Rome, demonstrating a clearer tendency toward climate aridity in the urban city than in peri-urban area. On the contrary, the specific characteristics of the suburban site, which is substantially far away from downtown Rome (approximately $10 \mathrm{~km}$ ) and surrounded by large green areas mixed with low-density residential settlements, may explain the inherent difference in aridity regimes. A distinctive effect of the UHI on air temperatures could be identified when comparing closer urban and peri-urban sites experiencing more rapid settlement expansion. Conversely, a visible effect of the urban heat island was likely associated with climate aridity rather than with individual rainfall or temperature variables. A significant trend toward climate aridity was observed at both sites, but the annual increase was higher in Collegio Romano than in Casalotti. In this case, climate aridity (more than local warming) reflects (i) a regional trend toward warming and (ii) the indirect impact of urban expansion in Rome. More generally, climatic trends incorporate a marked variability over time that is typical of the Agro Romano district with evident seasonality (contrasting a dry season including spring and summer and a wet season encompassing autumn and winter). Prolonged and anomalous weather conditions were observed in 2003, with average temperature above average $\left(17.2^{\circ} \mathrm{C}\right)$ and particularly low rainfall $(569 \mathrm{~mm})$; the 2006-2007 period was particularly hot with average temperatures above $16.5^{\circ} \mathrm{C}$ and rainfall below $600 \mathrm{~mm}$.

Profiling urban climate may benefit from the comparative analysis of weather variables in strictly urban and neighboring rural sites [83-85]. Unfortunately, data obtained from several meteorological stations are limited to rainfall and thermometric measures [6,57]. At the same time, urban climate can be regarded as the product of a 'cultural mediation' among the variety of approaches in design and planning, as far as materials and structures are concerned. In these regards, compact urban forms may recover definite micro-climate conditions [86-88]. A detailed analysis of the urban climate would help an organization of different kinds of settlement along the urban-rural gradient [33,34], e.g., a standard classification based on Local Climatic Zones [61]. Urban climatic regimes have features that explain a spatially-explicit approach for enduring monitoring and adaptation strategies. For instance, new technologies can be applied to the investigation of the effects of urban areas on the formation of precipitation, clouds and the storms [55-57], under the assumption that urbanization affects precipitation regimes by increasing the hygroscopic nuclei of condensation of atmospheric moisture. This was due to the increased air turbulence produced by the improved 'roughness' of the land surface and to convection triggered by the properties and different thermal states of the materials [79]. Furthermore, air conditioning of buildings, vehicular traffic and the quality of material for the covering of land surfaces contribute to heating, although the scarcity of green areas and low ventilation diminish the effectiveness of the natural systems for mitigation during these extreme events $[37,42]$. This hints at negative effects of climate change that can be worsened in urban zones 
and reduced along the urban gradient [89]. Focusing on natural resources, short and medium-term climatic changes and especially climate aridity may impact on water availability, agriculture water requirements and production of agro-forest landscapes in the Mediterranean region [89-91]. 'Dry' and 'hot' years are the most serious time periods since they feature harsh situations possibly harmful for vegetation and crop growth, particularly during the growing season. This information may cause overexploitation of water resources [46], e.g., from groundwater, triggering critical state due to rising withdrawals by civil use and agriculture [20] and other problems, e.g., salinization of groundwater [19].

Multi-scalar mitigation strategies at both national, regional and local scale are essential to manage with climate changes in metropolitan regions through explicit measures to adapt to climate change [92,93]. Policies for mitigation and adaptation to climate changes should improve sustainable strategies aimed at the most effective use of natural resources close to areas with high human pressure [37,42,46,94-96]. Approaches based on long-term climate forecasts and integrated with local-scale analysis of spatial variability in climate trends provide meaningful information to scenario investigation for future stability of peri-urban natural and agricultural environments in the Mediterranean basin [31,97-104]. Rome's expansion was assessed in the last years by focusing on the spatial demographic dynamics and the decline of the agricultural sector. Implications of global/local warming on peri-urban agriculture should be further investigated with the final objective to inform municipalities' policies supporting a sustainable land management $[47,96,104-109]$.

\section{Conclusions}

This study provides insights in local-scale climate regimes, distinguishing exogenous impact of global warming and regional influence of metropolitan expansion in a large urban region in Italy. Empirical evidence indicates a substantial impact of urban expansion in shaping local-scale climate variability, mainly temperature. Fringe agricultural land is recognized as effective green spaces mitigating the 'urban heat' effect. Design of more effective policies linking green infrastructures with more sustainable urban design are particularly relevant in mitigation and adaptation of peri-urban communities exposed to rapid urban expansion and accelerated climate variability.

Author Contributions: Conceptualization, L.S.; methodology, G.P. (Giu.P.); validation, A.C., M.C., L.P. and G.P. (Gio.P.); software preparation, S.C.; data standardization, S.C.; formal analysis, L.S.; investigation, L.S., L.P. and G.P. (Giu.P.); data curation, A.C. and I.Z.; writing-original draft preparation, I.Z.; visualization, A.C., M.C., L.P. and G.P. (Gio.P.); supervision, L.S.

Funding: This research received no external funding.

Conflicts of Interest: The authors declare no conflict of interest.

\section{References}

1. Olesen, J.E.; Bindi, M. Consequences of climate change for European agricultural productivity, land use and policy. Eur. J. Agron. 2002, 16, 239-262. [CrossRef]

2. IPCC (Intergovernmental Panel on Climate Change). Climate Change 2013: The Physical Science Basis. Available online: http://www.ipcc.ch/report/ar5/wg1/ (accessed on January 2014).

3. Brunetti, M.; Maugeri, M.; Monti, F.; Nanni, T. Temperature and precipitation variability in Italy in the last two centuries from homogenized instrumental time series. Int. J. Climatol. 2006, 26, 345-381. [CrossRef]

4. Brunetti, M.; Maugeri, M.; Nanni, T.; Navarra, A. Droughts and extreme events in regional daily Italian precipitation series. Int. J. Climatol. 2002, 22, 543-558. [CrossRef]

5. Founda, D.; Giannakopoulos, C. The exceptionally hot summer of 2007 in Athens, Greece-A typical summer in the future climate? Glob. Planet. Chang. 2009, 67, 227-236. [CrossRef]

6. Sivakumar, M.V.K. Interactions between climate and desertification. Agric. For. Meteorol. 2007, 142, $143-155$. [CrossRef]

7. Bajocco, S.; De Angelis, A.; Salvati, L. A satellite-based green index as a proxy for vegetation cover quality in a Mediterranean region. Ecol. Indic. 2012, 23, 578-587. [CrossRef] 
8. Ceccarelli, T.; Bajocco, S.; Perini, L.; Salvati, L. Urbanisation and Land Take of High Quality Agricultural Soils-Exploring Long-term Land Use Changes and Land Capability in Northern Italy. Int. J. Environ. Res. 2014, 8, 181-192.

9. Munafò, M.; Salvati, L.; Zitti, M. Estimating soil sealing at country scale-Italy as a case study. Ecol. Indic. 2013, 26, 36-43. [CrossRef]

10. Salvati, L.; Bajocco, S.; Ceccarelli, T.; Zitti, M.; Perini, L. Towards a process-based evaluation of soil vulnerability to degradation: A spatio-temporal approach in Italy. Ecol. Indic. 2011, 11, 1216-1227. [CrossRef]

11. Zambon, I.; Benedetti, A.; Ferrara, C.; Salvati, L. Soil Matters? A Multivariate Analysis of Socioeconomic Constraints to Urban Expansion in Mediterranean Europe. Ecol. Econ. 2018, 146, 173-183. [CrossRef]

12. Gualdi, S.; Navarra, A. Scenari climatici nel bacino mediterraneo. Forest J. Silvic. Forest Ecol. 2005, 2, 19.

13. Garcia Latorre, J.; Garcia-Latorre, J.; Sanchez-Picon, A. Dealing with aridity: Socio-economic structures and environmental changes in an arid Mediterranean region. Land Use Policy 2001, 18, 53-64. [CrossRef]

14. Venezian Scarascia, M.E.; Di Battista, F.; Salvati, L. Water resources in Italy: Availability and agricultural uses. Irrig. Drain. 2006, 55, 115-127. [CrossRef]

15. Colantoni, A.; Ferrara, C.; Perini, L.; Salvati, L. Assessing trends in climate aridity and vulnerability to soil degradation in Italy. Ecol. Indic. 2015, 48, 599-604. [CrossRef]

16. De Graaff, J.; Eppink, L.A.A.J. Olive oil production and soil conservation in southern Spain, in relation to EU subsidy policies. Land Use Policy 1999, 16, 259-267. [CrossRef]

17. Herrmann, S.M.; Hutchinson, C.F. The changing contexts of the desertification debate. J. Arid Environ. 2005, 63, 538-555. [CrossRef]

18. Perminova, T.; Laratte, B.; Sirina, N.; Baranovskaya, N.; Rikhvanov, L. Methods for land use impact assessment: A review. Environ. Impact Assess. Rev. 2016, 60, 64-74. [CrossRef]

19. Salvati, L.; Gemmiti, R.; Perini, L. Land degradation and the Mediterranean urban areas: An unexplored link with planning? Area 2012, 44, 317-325. [CrossRef]

20. Salvati, L.; Zitti, M.; Ceccarelli, T. Integrating economic and environmental indicators in the assessment of desertification risk: A case study. Appl. Ecol. Environ. Res. 2008, 6, 129-138. [CrossRef]

21. Salvati, L.; Zitti, M.; Perini, L. Fifty years on: Long-term patterns of land sensitivity to desertification in Italy. Land Degrad. Dev. 2016, 27, 97-107. [CrossRef]

22. Santos, M.; Cabral, J.A. Development of a stochastic dynamic model for ecological indicators' prediction in changed Mediterranean agroecosystems of north-eastern Portugal. Ecol. Indic. 2003, 3, 285-303. [CrossRef]

23. Emadodin, I.; Bork, H.R. Degradation of soils as a result of long-term human-induced transformation of the environment in Iran: An overview. J. Land Use Sci. 2011, 7, 203-219. [CrossRef]

24. Emadodin, I.; Reiss, S.; Bork, H.R. A study of the relationship between land management and soil aggregate stability: A case study near Albersdorf, Northern-Germany. J. Agric. Biol. Sci. 2009, 4, 48-53.

25. Imeson, A. Desertification, Land Degradation and Sustainability; Wiley: Chichester, UK, 2012; Volume 3, p. 336.

26. Zdruli, P. Land resources of the Mediterranean: Status, pressures, trends and impacts on future regional development. Land Degrad. Dev. 2014, 25, 373-384. [CrossRef]

27. Zinck, J.A.; Berroteran, J.L.; Farshad, A.; Moameni, A.; Wokabi, S.; Van Ranst, E. Approaches to assessing sustainable agriculture. J. Sustain. Agric. 2004, 23, 87-109. [CrossRef]

28. Feoli, E.; Giacomich, P.; Mignozzi, K.; Oztürk, M.; Scimone, M. Monitoring desertification risk with an index integrating climatic and remotely-sensed data: An example from the coastal area of Turkey. Manag. Environ. Qual. An. Int. J. 2003, 14, 10-21. [CrossRef]

29. Lavado Contador, J.F.; Schnabel, S.; Gomez Gutierrez, A.; Pulido Fernandez, M. Mapping sensitivity to land degradation in Extremadura, SW Spain. Land Degrad. Dev. 2009, 20, 129-144. [CrossRef]

30. Montanarella, L. Trends in Land Degradation in Europe; Sivakumar, M.V., N'diangui, N., Eds.; Climate and Land Degradation. Environmental Science and Engineering (Environmental Science); Springer: Berlin, Germany, 2007. [CrossRef]

31. Zambon, I.; Serra, P.; Sauri, D.; Carlucci, M.; Salvati, L. Beyond the 'Mediterranean City': Socioeconomic Disparities and Urban Sprawl in three Southern European Cities. Geogr. Ann. B 2017, 99, 319-337. [CrossRef]

32. Mirzaei, P.A. Recent challenges in modeling of urban heat island. Sustain. Cities Soc. 2015, 19, $200-206$. [CrossRef]

33. Zinzi, M.; Carnielo, E.; Mattoni, B. On the relation between urban climate and energy performance of buildings. A three-year's experience in Rome, Italy. Appl. Energy 2018, 221, 148-160. [CrossRef] 
34. Palme, M.; Inostroza, L.; Villacreses, G.; Lobato-Cordero, A.; Carrasco, C. From urban climate to energy consumption. Enhancing building performance simulation by including the urban heat island effect. Energy Build. 2017, 145, 107-120. [CrossRef]

35. Rosenzweig, C.; Solecki, W.; Hammer, S.A.; Mehrotra, S. Cities lead the way in climate-change action. Nature 2010, 467, 909. [CrossRef]

36. Santamouris, M.; Kolokotsa, D. On the impact of urban overheating and extreme climatic conditions on housing, energy, comfort and environmental quality of vulnerable population in Europe. Energy Build. 2015, 98, 125-133. [CrossRef]

37. Rizwan, A.M.; Dennis, L.Y.C.; Liu, C. A review on the generation, determination and mitigation of urban heat island. J. Environ. Sci. 2008, 20, 120-128. [CrossRef]

38. Ward, K.; Lauf, S.; Kleinschmit, B.; Endlicher, W. Heat waves and urban heat islands in Europe: A review of relevant drivers. Sci. Total Environ. 2016, 569, 527-539. [CrossRef]

39. Voogt, J.A.; Oke, T.R. Thermal remote sensing of urban climates. Remote Sens. Environ. 2003, 86, 370-384. [CrossRef]

40. Gabriel, K.M.; Endlicher, W.R. Urban and rural mortality rates during heat waves in Berlin and Brandenburg, Germany. Environ. Pollut. 2011, 159, 2044-2050. [CrossRef]

41. Kovats, R.S.; Hajat, S. Heat stress and public health: A critical review. Annu. Rev. Public Health 2008, 29, 41-55. [CrossRef]

42. Gartland, L.M. Heat Islands: Understanding and Mitigating Heat In Urban Areas; Routledge: London, UK, 2012; p. 208. [CrossRef]

43. Stewart, I.D.; Oke, T.R. Local climate zones for urban temperature studies. Bull. Am. Meteorol. Soc. 2012, 93, 1879-1900. [CrossRef]

44. Jacob, D.; Kotova, L.; Teichmann, C.; Sobolowski, S.P.; Vautard, R.; Donnelly, C.; Sakalli, A. Climate Impacts in Europe Under $+1.5^{\circ} \mathrm{C}$ Global Warming. Earth's Future 2018, 6, 264-285. [CrossRef]

45. Carlucci, M.; Grigoriadis, E.; Rontos, K.; Salvati, L. Revisiting An Hegemonic Concept: Long-term 'Mediterranean Urbanization' in between city re-polarization and metropolitan decline. Appl. Spatial Anal. Policy 2017, 10, 347-362. [CrossRef]

46. Salvati, L.; Petitta, M.; Ceccarelli, T.; Perini, L.; Di Battista, F.; Venezian Scarascia, M.E. Italy's renewable water resources as estimated on the basis of the monthly water balance. Irrig. Drain. 2008, 57, 507-515. [CrossRef]

47. Duvernoy, I.; Zambon, I.; Sateriano, A.; Salvati, L. Pictures from the Other Side of the Fringe: Urban Growth and Peri-urban Agriculture in a Post-industrial City (Toulouse, France). J. Rural Stud. 2018, 57, 25-35. [CrossRef]

48. Biasi, R.; Colantoni, A.; Ferrara, C.; Ranalli, F.; Salvati, L. In-between Sprawl and Fires: Long-term Forest Expansion and Settlement Dynamics at the Wildland-Urban Interface in Rome, Italy. Int. J. Sustain. Dev. World Ecol. 2015, 22, 467-475. [CrossRef]

49. Colantoni, A.; Grigoriadis, E.; Sateriano, A.; Venanzoni, G.; Salvati, L. Cities as selective land predators? A lesson on urban growth, deregulated planning and sprawl containment. Sci. Total Environ. 2016, 545, 329-339. [CrossRef]

50. Colantoni, A.; Mavrakis, A.; Sorgi, T.; Salvati, L. Towards a 'polycentric'landscape? Reconnecting fragments into an integrated network of coastal forests in Rome. Rend. Lincei 2015, 26, 615-624. [CrossRef]

51. Cuadrado-Ciuraneta, S.; Durà-Guimerà, A.; Salvati, L. Not only tourism: Unravelling suburbanization, second-home expansion and rural sprawl in Catalonia, Spain. Urban. Geogr. 2017, 38, 66-89. [CrossRef]

52. Loret, E.; Marino, L.; Fea, M.; Sarti, F. Combined Remote Sensing and GIS Techniques for Studying the Large Roman Urban System Expansion during the Last Twenty Years. Adv. Remote Sens. 2015, 4, 48-62. [CrossRef]

53. Pesaresi, C.; Marta, M.; Palagiano, C. The causes of death in the province of Rome between 1981 and 2007: A geographical analysis. Geogr. Environ. Sustain. 2011, 4, 24-47. [CrossRef]

54. McKee, T.B.; Doesken, N.J.; Kliest, J. The relationship of drought frequency and duration to time scales. In Proceedings of the 8th Conference on Applied Climatology, Anaheim, CA, USA, 17-22 January 1993; Meteorol. Soc. Bost. pp. 179-184.

55. McKee, T.B.; Doesken, N.J.; Kleist, J. Drought monitoring with multiple time scales. In Proceedings of the 9th Conference on Applied Climatology, Dallas, TX, USA, 15-20 January 1995; Meteorol. Soc. pp. 233-236.

56. Guttman, N.B. Comparing the Palmer drought index and the standardized precipitation index. J. Am. Water Res. Assoc. 1998, 34, 113-121. [CrossRef] 
57. Patel, N.R.; Chopra, P.; Dadhwal, V.K. Analyzing spatial patterns of meteorological drought using standardized precipitation index. Meteorol. Appl. 2007, 14, 329-336. [CrossRef]

58. Kumar, M.N.; Murthy, C.S.; Sesha Sai, M.V.R.; Roy, P.S. Spatiotemporal analysis of meteorological drought variability in the Indian region using standardized precipitation index. Meteorol. Appl. 2012, 19, 256-264. [CrossRef]

59. Zhang, A.; Jia, G. Monitoring meteorological drought in semiarid regions using multi-sensor microwave remote sensing data. Remote Sens. Environ. 2013, 134, 12-23. [CrossRef]

60. Belayneh, A.; Adamowski, J.; Khalil, B.; Ozga-Zielinski, B. Long-term SPI drought forecasting in the Awash River Basin in Ethiopia using wavelet neural network and wavelet support vector regression models. J. Hydrol. 2014, 508, 418-429. [CrossRef]

61. Bechtel, B.; Alexander, P.J.; Böhner, J.; Ching, J.; Conrad, O.; Feddema, J.; Mills, G.; See, L.; Stewart, I. Mapping Local Climate Zones for a Worldwide Database of the Form and Function of Cities. ISPRS Int. J. Geo-Inf. 2015, 4, 199-219. [CrossRef]

62. Easterling, D.R.; Meehl, G.A.; Parmesan, C.; Changnon, S.A.; Karl, T.R.; Mearns, L.O. Climate Extremes: Observations, Modeling, and Impacts. Science 2000, 289, 2068-2074. [CrossRef] [PubMed]

63. Cook, B.I.; Smerdon, J.E.; Seager, R.; Coats, S. Global warming and 21st century drying. Clim. Dyn. 2014, 43, 2607-2627. [CrossRef]

64. Kelley, C.P.; Mohtadi, S.; Cane, M.A.; Seager, R.; Kushnir, Y. Climate change in the Fertile Crescent and implications of the recent Syrian drought. PNAS 2015, 112, 3241-3246. [CrossRef]

65. Lesk, C.; Rowhani, P.; Ramankutty, N. Influence of extreme weather disasters on global crop production. Nature 2016, 529, 84-87. [CrossRef]

66. Mearns, L.O.; Katz, R.W.; Schneider, S.H. Extreme High-Temperature Events: Changes in their probabilities with Changes in Mean Temperature. J. Clim. Appl. Meteor. 1984, 23, 1601-1613. [CrossRef]

67. Katz, R.W.; Brown, B.G. Extreme events in a changing climate: Variability is more important than averages. Clim. Chang. 1992, 21, 289-302. [CrossRef]

68. Meehl, G.A.; Karl, T.; Easterling, D.R.; Changnon, S.; Pielke, R.; Changnon, D.; Evans, J.; Groisman, P.Y.; Knutson, T.R.; Kunkel, K.E. An Introduction to Trends in Extreme Weather and Climate Events: Observations, Socioeconomic Impacts, Terrestrial Ecological Impacts, and Model Projections. Bull. Am. Meteor. Soc. 2000, 81, 413-416. [CrossRef]

69. Zhang, J.; Shen, Y. Spatio-temporal variations in extreme drought in China during 1961-2015. J. Geogr. Sci. 2019, 29, 67-83. [CrossRef]

70. Keyantash, J.; Dracup, J.A. The Quantification of Drought: An Evaluation of Drought Indices. Bull. Am. Meteor. Soc. 2002, 83, 1167-1180. [CrossRef]

71. Lloyd-Hughes, B.; Saunders, M.A. A drought climatology for Europe. Int. J. Clim. 2002, 22, 1571-1592. [CrossRef]

72. Perini, L.; Salvati, L.; Zitti, M.; Bajocco, S. A proposal for a meteorological index of climate change impact. J. Agrometeorol. 2011, 1, 1-11.

73. Castan Broto, V.; Bulkeley, H. A survey of urban climate change experiments in 100 cities. Glob. Environ. Chang. 2013, 23, 92-102.

74. Hallegatte, S.E.; Corfee-Morlot, J. Understanding climate change impacts, vulnerability and adaptation at city scale: An introduction. Clim. Chang. 2011, 104, 1-12.

75. Hallegatte, S.; Henriet, F.; Corfee-Morlot, J. The economics of climate change impacts and policy benefits at city scale: A conceptual framework. Clim. Chang. 2011, 104, 51-87. [CrossRef]

76. Hunt, A.E.; Watkiss, P. Climate change impacts and adaptation in cities: A review of the literature. Clim. Chang. 2011, 104, 13-49. [CrossRef]

77. István, L.B. Urban sprawl and climate change: A statistical exploration of cause and effect, with policy options for the EU. Land Use Policy 2010, 27, 283-292.

78. Medri, S.; Venturini, S.; Castellari, S. Overview of key climate change impacts, vulnerabilities and adaptation action in Italy. CMCC Res. Pap. 2013, 178. [CrossRef]

79. Philandras, C.M.; Metaxas, D.A.; Nastos, P.T. Climate variability and urbanization in Athens. Theor. Appl. Clim. 1999, 63, 65-72. [CrossRef]

80. Westerhoff, L.; Keskitalo, E.C.H.; Juhola, S. Capacities across scales: Local to national adaptation policy in four European countries. Clim. Policy 2011, 11, 1071-1085. [CrossRef] 
81. Incerti, G.; Feoli, E.; Giovacchini, A.; Salvati, L.; Brunetti, A. Drought estimation through a neural network approach. Int. J. Biometeorol. 2007, 51, 253-263. [CrossRef] [PubMed]

82. Salvati, L.; Perini, L.; Sabbi, A.; Bajocco, S. Climate aridity and land use changes: A regional-scale analysis. Geogr. Res. 2012, 50, 193-203. [CrossRef]

83. Wu, H.; Wilhite, D.A. An operational agricultural drought risk assessment model for Nebraska, USA. Nat. Hazards 2004, 33, 1-21. [CrossRef]

84. Hawkins, T.W.B.; Stefanov, W.L.; Bigler, W.; Saffell, E.M. The role of rural variability in urban heat island determination for Phoenix, Arizona. J. Appl. Meteorol. 2004, 43, 476-486. [CrossRef]

85. Sakakibara, Y.E.; Owa, K. Urban rural temperature differences in coastal cities: Influence of rural sites. Int. J. Clim. 2005, 25, 811-820. [CrossRef]

86. Boubaker, K.; Colantoni, A.; Allegrini, E.; Longo, L.; Di Giacinto, S.; Monarca, D.; Cecchini, M. A model for musculoskeletal disorder-related fatigue in upper limb manipulation during industrial vegetables sorting. Int. J. Ind. Ergon. 2014, 44, 601-605. [CrossRef]

87. Marucci, A.; Monarca, D.; Cecchini, M.; Colantoni, A.; Biondi, P.; Cappuccini, A. The heat stress for workers employed in laying hens houses. J. Food Agric. Environ. 2013, 11, $20-24$.

88. Marucci, A.; Pagniello, B.; Monarca, D.; Cecchini, M.; Colantoni, A.; Biondi, P. Heat stress suffered by workers employed in vegetable grafting in greenhouses. J. Food Agric. Environ. 2012, 10, 1117-1121.

89. Szymanowski, M. Interactions between thermal advection in frontal zones and the urban heat island of Wroclaw, Poland. Theor. Appl. Clim. 2005, 82, 207-224. [CrossRef]

90. Burri, E.; Petitta, M. Agricultural changes affecting water availability: From abundant to scarcity conditions (Fucino Plain, Central Italy). Irrig. Drain. 2004, 53, 287-299. [CrossRef]

91. Kairis, O.; Karavitis, C.; Kounalaki, A.; Fasouli, V.; Salvati, L.; Kosmas, K. Exploring the Impact of Overgrazing and Sustainable Grazing on Soil Erosion and Land Degradation in a Mediterranean Agro-forest Landscape (Crete, Greece). Arid Land Res. Manag. 2015, 29, 360-374. [CrossRef]

92. Salvati, L. Agro-forest landscape and the 'fringe' city: A multivariate assessment of land-use changes in a sprawling region and implications for planning. Sci. Total Environ. 2014, 490, 715-723. [CrossRef] [PubMed]

93. Delladetsima, P.M. The emerging property development pattern in Greece and its impact on spatial development. Eur. Urban. Reg. Stud. 2006, 13, 245-278. [CrossRef]

94. Monarca, D.; Cecchini, M.; Guerrieri, M.; Colantoni, A. Conventional and Alternative Use of Biomasses Derived by Hazelnut Cultivation and Processing. In Proceedings of the VII International Congress on Hazelnut 845, Viterbo, Italy, 23-27 June 2008; 2008; pp. 627-634.

95. Monarca, D.; Cecchini, M.; Colantoni, A.; Marucci, A. Feasibility of the Electric Energy Production through Gasification Processes of Biomass: Technical and Economic Aspects. In International Conference on Computational Science and Its Applications; Springer: Berlin/Heidelberg, Germany, June 2011; pp. 307-315.

96. Zambon, I.; Colantoni, A.; Cecchini, M.; Mosconi, E. Rethinking sustainability within the viticulture realities integrating economy, landscape and energy. Sustainability 2018, 10, 320. [CrossRef]

97. Dura-Guimera A Population deconcentration and social restructuring in Barcelona, a European Mediterranean city. Cities 2003, 20,387-394. [CrossRef]

98. European Environment Agency. Urban Sprawl in Europe-the Ignored Challenge; EEA Report no. 10; European Environment Agency: Copenhagen, Denmark, 2006.

99. Kazemzadeh-Zow, A.; Zanganeh Shahraki, S.; Salvati, L.; Neisani Samani, N. A Spatial Zoning Approach to Calibrate and Validate Urban Growth Models. Int. J. Geogr. Inf. Sci. 2017, 31, 763-782. [CrossRef]

100. Rontos, K.; Grigoriadis, S.; Sateriano, A.; Syrmali, M.; Vavouras, I.; Salvati, L. Lost in Protest, Found in Segregation: Divided Cities in the Light of the 2015 'Oki' Referendum in Greece. City Cult. Soc. 2016, 7, 139-148. [CrossRef]

101. Zitti, M.; Ferrara, C.; Perini, L.; Carlucci, M.; Salvati, L. Long-term Urban Growth and Land-use Efficiency in Southern Europe: Implications for Sustainable Land Management. Sustainability 2015, 7, 3359-3385. [CrossRef]

102. Colombo, A.F.; Etkin, D.; Karney, B.W. Climate variability and the frequency of extreme temperature events for nine sites across Canada: Implications for power usage. J. Clim. 1999, 12, 2490-2502. [CrossRef]

103. Meehl, G.A.; Zwiers, F.; Evans, J.; Knutson, T.; Mearns, L.; Whetton, P. Trends in extreme weather and climate events: Issues related to modeling extremes in projections of future climate change. Bull. Am. Meteorol. Soc. 2000, 81, 427-436. [CrossRef] 
104. Abbas, F.; Hammad, H.M.; Fahad, S.; Cerdà, A.; Rizwan, M.; Farhad, W.; Bakhat, H.F. Agroforestry: A sustainable environmental practice for carbon sequestration under the climate change scenarios-A review. Environ. Sci. Pollut. Res. 2017, 24, 11177-11191. [CrossRef]

105. Ochoa, P.A.; Fries, A.; Mejía, D.; Burneo, J.I.; Ruíz-Sinoga, J.D.; Cerdà, A. Effects of climate, land cover and topography on soil erosion risk in a semiarid basin of the Andes. Catena 2016, 140, 31-42. [CrossRef]

106. Corona, P. Forestry research to support the transition towards a bio-based economy. Ann. Silvic. Res. 2015, 38, 37-38.

107. Stojanović, D.; Levanič, T.; Matović, B.; Bravo-Oviedo, A. Climate change impact on a mixed lowland oak stand in Serbia. Ann. Silvic. Res. 2015, 39, 94-99.

108. Marchi, M.; Castaldi, C.; Merlini, P.; Nocentini, S.; Ducci, F. Stand structure and climate influence on the growth trends of a marginal forest population of Pinus nigra spp. nigra. Ann. Silvic. Res. 2015, 39, 100-110.

109. Fardusi, M.J.; Chianucci, F.; Barbati, A. Concept to practice of geospatial-information tools to assist forest management and planning under precision forestry framework: A review. Ann. Silvic. Res. 2017, 41, 3-14.

(C) 2019 by the authors. Licensee MDPI, Basel, Switzerland. This article is an open access article distributed under the terms and conditions of the Creative Commons Attribution (CC BY) license (http://creativecommons.org/licenses/by/4.0/). 